Info Artikel:

\title{
Apakah spiritualitas berkontribusi terhadap kesehatan mental mahasiswa?
}

\author{
Esa Nur Wahyuni ${ }^{1}$, Khairul Bariyyah ${ }^{2}$ \\ ${ }^{1}$ Universitas Islam Negeri Maulana Malik Ibrahim Malang, ${ }^{2}$ Universitas Kanjuruhan Malang
}

\begin{abstract}
Spirituality and mental health have become important studies in the world of education. The holistic education paradigm views the two aspects as having a very important role in determining the best development of students and their learning achievements in addition to cognitive and skill aspects. Theoretically mental health is influenced by spirituality. This study examined the effect of student spirituality on mental health in 382 new FITK Uin students Maulana Malik Ibrahim Malang. The level of mental health was measured using a mental health scale developed by Ryff and Keyes, while spirituality was measured by Religiosity and Spirituality Scale for Youth by Hernandez. The results showed the influence of spirituality on health as much as $r=0.295$ and sig. amounting to 0.01. These results explain that spirituality is one of the factors that affect the level of mental health of new students
\end{abstract}

Keywords: spiritualitas, kesehatan mental

This is an open access article distributed under the Creative Commons Attribution License, which permits unrestricted use,
distribution, and reproduction in any medium, provided the original work is properly cited. C2019 by author.

\section{PENDAHULUAN}

Kesehatan mental telah menjadi isu penting dalam dunia pendidikan, khususnya di perguruan tinggi. Hal tersebut tidak terlepas dari adanya fakta bahwa kesehatan mental memiliki kontribusi terhadap perkembangan dan kesuksesan akademik mahasiswa. Bahkan kesehatan mental yang bermasalah dapat berdampak cukup kuat terhadap kehidupan lingkungan kampus. Baik pada level individual, interpersonal, maupun level institusional (Kitzrow, 2009).

Pada level individual, problema kesehatan mental berpengaruh terhadap semua aspek yang ada pada diri mahasiswa, baik aspek emosional, kognitif, fisik, dan sosial. Problema kesehatan mental dapat dilihat dalam bentuk munculnya gejala-gejala umum depresi seperti terganggunya suasana hati, stress, (Blanco et al., 2008), keletihan, lemahnya energi, problema dengan pola makan dan tidur, konsentrasi yang buruk, rendahnya motivasi dan self esteem, lemahnya kemampuan mengingat dan pengambilan keputusan, hilangnya semangat untuk menjalani aktivitas secara normal dan menarik diri dari lingkungan sosial, serta kondisi yang lebih esktrim melarikan diri dari rumah dan bahkan bunuh diri (Blanco et al., 2008); Alzaeem, Sulaiman, \& Gillani, 2010; Carter, 2016). tingkat distress psikologis yang tinggi diantara para mahasiswa secara signifikan dikaitkan dengan performan akademik. Karakteristik mahasiswa dengan tingkat distress psikologi yang tinggi ditunjukkan dengan skor tes kecemasan yang tinggi, rendahnya self efficacy pada bidang akademik, kemampuan mengelola waktu dan penggunaan sumber-sumber belajar yang kurang efektif, kurang mampu menghadapi kondisi sulit, rendahnya kemampuan menggunakan strategi-strategi belajar (Brackney \& Karabenick, 1995a). 
Secara interpersonal, mahasiswa dengan kondisi kesehatan mental yang bermasalah cenderung memiliki masalah secara emosional maupun perilaku dalam bentuk perilaku-perilaku distruptif, mengganggu, dan perilaku-perilaku berbahaya lainnya, bahkan yang lebih ekstrim adalah perilaku menyakiti diri sendiri maupun orang lain. Kondisi demikian akan dapat mengganggu hubungan mereka dengan orang lain, baik dengan teman sekelas, para staff, ataupun pengajar menjadi kurang harmonis (Alzaeem et al., 2010).

Secara institusional, setiap perguruan tinggi memiliki visi dan misi yang akan dicapai. Pencapaian visi dan misi tersebut perlu didukung oleh seluruh sivitas akademik yang salah satu diantaranya adalah mahasiswa. Dalam konteks ini, kesehatan mental mahasiswa baik secara langsung maupun tidak dapat memberi dampak terhadap keberhasilan pencapaian visi dan misi perguruan tinggi.

Kesehatan mental tidak ada dengan sendirinya, tetapi bagian integral dan esensial dari kesehatan secara keseluruhan, yang dapat didefinisikan setidaknya dalam tiga cara, yaitu sebagai tidak adanya penyakit, sebagai keadaan organisme yang memungkinkan kinerja penuh semua fungsinya atau sebagai keadaan keseimbangan dalam diri seseorang dan antara diri sendiri dan lingkungan fisik serta sosial seseorang (Sartorius, 2002). Menurut Maslow (1968 dalam Bhugra, Till, \& Sartorius, 2013) manakah dari tiga definisi yang digunakan tergantung pada tingkat pemenuhan kebutuhan kesehatan dasar, termasuk kebutuhan akan makanan, tempat tinggal, kelangsungan hidup, perlindungan, masyarakat, dukungan sosial, dan bebas dari rasa sakit, bahaya lingkungan, stress yang tidak perlu dan dari setiap bagian eksploitasi.

Kesehatan mental seorang individu dapat dipahami sebagai kondisi yang menyiratkan bahwa individu memiliki kemampuan untuk membentuk dan memelihara hubungan kasih sayang dengan orang lain, untuk tampil dalam peran sosial sesuai dengan budaya mereka dan untuk mengelola perubahan, mengenali, mengakui, dan mengkomunikasikan tindakan positif dan pikiran serta untuk mengelola emosi seperti kesedihan. Kesehatan mental memberikan perasaan berharga, kontrol, dan pemahaman fungsi internal dan eksternal. Dengan demikian kesehatan mental dapat dipahami sebagai kesejahteraan yang dialami oleh individu terkait tiga aspek yaitu, aspek biologis, sosial, dan psikologis (Manwell et al., 2015;Bhugra et al., 2013; Keyes \& Lopez, 2002).

Banyak faktor yang mempengaruhi kesehatan mental, salah satu diantaranya adalah spiritualitas. Spiritualitas dipahami sebagai sesuatu yang bersifat transenden, mengarah kepada pencarian makna hidup, dan memahami hidup (Park et al., 2013). Spiritualitas juga bersifat personal, afektif, pengalaman, dan kebijaksanaan. Spiritualitas mengandung nilai-nilai yang bersifat rohani, seberti kejujuran, keindahan, dan kebahagiaan. Beberapa penelitian menunjukkan spiritualitas memiliki pengaruh terhadap kondisi kesehatan mental individu. Spiritualitas dan religiusitas mampu memberikan kekuatan bagi individu yang mengalami emosi negatif dan keinginan untuk bunuh diri, serta meningkatkan resiliensi ketika menghadapi tekan hidup (Hodapp \& Zwingmann, 2019; Dangel, 2019; Koenig \& Al Shohaib, 2019).

Disisi lain, tingkat kesehatan mental dan spiritualitas juga dihubungkan dengan jenis kelamin. Jenis kelamin dalam konteks penelitian ini adalah dua jenis bentuk kelamin yang membedakan secara tegas individu perempuan dan laki-laki khususnya terkait dengan organ dan fungsi reproduksi. Hasil penelitian yang beragam menunjukkan beberapa penelitian menyatakan jenis kelamin memiliki hubungan dengan kesehatan mental (Etopio, Devereux, \& Crowder, 2018; Logan \& Walker, 2017). Namun beberapa peneliti lain menemukan bahwa tidak ada keterkaitan antara jenis kelamin dengan kesehatan mental (Hasson-Ohayon, MashiachEizenberg, Lavi-Rotenberg, Brüne, \& Roe, 2019; Pant \& Srivastava, 2019; Jafari et al., 2010)

Mahasiswa baru adalah individu yang berada pada masa transisi antara menuju masa dewasa yang berpotensi mengalami kondisi tidak stabil secara psikologis maupun sosial. Selain itu mereka juga berpotensi menghadapi tekanan dalam proses adaptasi dengan budaya belajar di perguruan tinggi yang berbeda dengan budaya belajar ketika berada pada jenjang pendidikan sekolah menengah. Secara teoritis tingkat spiritualitas mahasiswa dapat mempengaruhi kesehatan mental. Sedangkan secara empiris perlu ada pengujian pengaruh spiritualitas terhadap kesehatan mental mahasiswa baru dengan jenis kelamin yang berbeda. 
Berdasarkan latar belakang yang telah dipaparkan penelitian ini bertujuan untuk pertama menguji tingkat spiritulitas mahasiswa baru sebagai individu-individu yang berada pada kelompok usia muda, dan bagaimana kekuatan spiritulitas mahasiswa baru berpengaruh terhadap kesehatan mentalnya. Kedua, mengidentifikasi perbedaan spiritual dan kesehatan mental lintas gender.

\section{METODE}

Subyek dalam penelitian ini adalah mahasiswa baru di fakultas Ilmu Tarbiyah dan Kependidikan (FITK) Universitas Islam Negeri Maulana Malik Ibrahim Malang. Subyek penelitian sebanyak 200 orang. Pemilihan mahasiswa baru didasarkan pada pertimbangan bahwa 1) mahasiswa baru adalah kaum muda yang usianya berkisar antara 18-20 tahun. Mereka merupakan individu yang berada pada tahap dewasa awal. Pada tahap perkembangan ini, meskipun sudah relatif lebih stabil secara psikologis dibandingkan usia sebelumnya (remaja awal), tetapi mereka masih mengalami kondisi ketidakstabilan emosi akibat proses pencarian identitas diri yang belum selesai. Kondisi tersebut dapat menjadi faktor yang berisiko bagi kesehatan mental mereka. 2) mahasiswa baru diwajibkan untuk menghuni Ma'had Sunan Ampel Ali (MSAA) selama dua semester. MSAA adalah sebuah asrama untuk mahasiswa baru di UIN Malang, di mana mereka mendapatkan pendidikan dan pembinaan untuk pengembangan kepribadian, keagamaan, moral, dan akademik. Akan tetapi dalam pelaksanaannya, tujuan tersebut tidak selalu berjalan dengan baik. Karakteristik MSAA sebagai tempat tinggal bersama seluruh mahasiswa baru, menuntut mereka melakukan perubahan kebiasaan agar dapat menyesuaikan diri dengan baik. Namun kenyataannya, tidak semua mahasiswa di MSAA dapat melakukan peyesuaian diri dengan baik sehingga menimbulkan banyak masalah dan tidak jarang mahasiswa baru mengalami persoalan-persoalan psikologis. Ketiga, dari aspek spirtualitas dan religiusitas, mahasiswa baru UIN Maliki Malang memiliki latar belakang keluarga dan pendidikan yang menguatkan spiritualitas atau religiusitas mereka.

Dua instrumen pengumpulan data penelitian yang digunakan dalam penelitian ini yaitu; (1) Instrumen untuk mengukur tingkat spiritualitas mahasiswa adalah The Religiosity And Spirituality Scale For Youth (RSYS) yang dikembangkan oleh Hernandez (2011). RSYS merupakan skala likert yang terdiri atas 5 range jawaban, yaitu sangat benar, benar, cukup benar, kurang benar, tidak benar. Variabel ini memuat dua aspek spiritualitas, yaitu aspek Faith based coping dan Religious Social Support/Activities. Pengujian validitas dan relibilitas terhadap instrumen spiritualitas diperoleh nilai $\alpha$ sebesar 0,902 . Nilai koefesien korelasi antara 0,302 sampai dengan 0,620. Tabel 1 menjelaskan kisi-kisi instrument mengukur spiritualitas mahasiswa.

Tabel 1. Kisi-kisi Instrumen Spiritualitas

\begin{tabular}{lll}
\hline Varibel & Indikator & Item \\
\hline Spiritualitas & Religious Social & $2,5,6,12,14,16,18,21,22,24,25,32,36$, \\
& Support/Activities & \\
& Faith-Based Coping & $1,3,4,7,8,9,10,11,13,15,17,19,2023,26,27$, \\
& & $28,29,30,31,33,34,35,37$ \\
\hline
\end{tabular}

(2) Instrumen untuk mengukur tingkat kesehatan mental. Dikembangkan dari konstruk kesehatan mental yang dikemukakan oleh keyes dan Lopes, yang menyatakan kesehatan mental terdiri atas dua dimensi, yaitu dimensi sejahtera secara psikologi (psychology wellbeing) dan sosial (social wellbeing). Dalam instrumen pengukuran dimensi psychological wellbeing diindikasikan dengan self acceptance, Purpose in life, Environmental Mastery, Autonomy, Positive relation with others. Sedangkan dimensi sejahtera sosial meliputi; social acceptance, Social actualization, Social coheren, Social integration. Hasil pengujian reliabilitas terhadap instrumen kesehatan mental diperoleh $\alpha$ sebesar 0,745. Kisi-kisi pengukuran kesehatan mental dapat dijelaskan lebih rinci pada tabel 2. 
Tabel 2. Kisi-kisi Kesehatan Mental

\begin{tabular}{llll}
\hline Variabel & \multicolumn{1}{c}{ Indikator } & Deskriptor & Item \\
\hline Kesehatan Mental & Kesejahteraan Psikologi & self acceptance, & $7,8,15$ \\
& & Purpose in life, & $12,13,14$ \\
& & Environmental Mastery & $4,5,6$ \\
& Autonomy & $1,2,3$ \\
& Positive relation with others & $9,10,11$ \\
& Personal growth & 16,17 \\
& & \\
& & Social integration & $2,6,11$ \\
& Kesejahteraan Sosial & Social acceptance & $3,10,14$ \\
& & Social contribution & $4,7,15$ \\
& Social coherence & $5,9,13$ \\
& & $1,8,12$ \\
\hline
\end{tabular}

Semua data yang diperoleh dari skala spiritualitas dan kesehatan mental dianalisis dengan menggunakan analisis regresi untuk menguji hubungan, sedangkan uji t digunakan untuk menguji perbedaan jenis kelamin terhadap kesehatan mental dan spiritualitas. Semua analisis statistik dilakukan dengan bantuan software tambahan Microsoft Excel dan SPPS.

\section{HASIL PENELITIAN DAN PEMBAHASAN}

Penelitian ini dilakukan untuk menguji dampak spiritualitas dan jenis kelamin terhadap kesehatan mental. Oleh karena itu pertama yang dieksplorasi adalah skor rata-rata dan standar deviasi, selanjutnya dijelaskan hasil analisis untuk hipotesa 1. Pada tabel 3 menjelaskan tentang skor rata-rata dan standar deviasi dari spiritualitas dan kesehatan mental.

Tabel 3. Skor rata-rata dan Standar Deviasi Spiritualitas dan Kesehatan Mental Mahasiswa

\begin{tabular}{lrllll}
\hline \multicolumn{1}{c}{ Variabel } & N & Minimum & Maximum & Mean (M) & Standar Deviasi (SD) \\
\hline Spiritualitas & 382 & 29.00 & 74 & 58.74 & 7.424 \\
Mahasiswa Laki-laki & 100 & 33.00 & & 58.73 & 7.69 \\
Mahasiswa Perempuan & 282 & 29.00 & & 58.74 & 7.34 \\
Kesehatan Mental & 382 & 72 & 140 & 109.36 & 10.349 \\
Mahasiswa Laki-laki & 100 & & & & \\
Mahasiswa Perempuan & 282 & & & & \\
\hline
\end{tabular}

Berdasarkan hasil pengujian deskriptif tingkat kesehatan mental dapat dilihat pada tabel 4 berikut.

Tabel 4. Tingkat Kesehatan Mental Subyek Penelitian

\begin{tabular}{lccc}
\hline & Kriteria & Jumlah & Persentase \\
\hline Tinggi & 48 & 27 & \\
Sedang & 104 & 58,4 \\
Rendah & 26 & 14,6 \\
\hline Jumlah & 178 & 100 \\
\hline
\end{tabular}

Dari table 4.2 dapat diketahui bahwa sebanyak 48 (27\%) subyek penelitian berada pada kategori tinggi, dan sebanyak $104(58,4 \%)$ berada kategori sedang, serta $26(14,6 \%)$ berada pada kategori rendah. Dengan demikian dapat disimpulkan sebagian besar tingkat kesehatan mental subyek penelitian berada pada tingkat sedang. Pada variabel spiritualitas, hasil analisis deskriptif tingkat spiritualitas mahasiswa dapat dilihat pada tabel 5 sebagai berikut. 
Tabel 5. Kategori Tingkat Spiritual Subyek Penelitian

\begin{tabular}{|c|c|c|}
\hline Kategori & Jumlah & Persentase \\
\hline Tinggi & 26 & 14,6 \\
\hline Sedang & 126 & 70,8 \\
\hline Rendah & 26 & 14,6 \\
\hline Jumlah & 178 & 100 \\
\hline
\end{tabular}

Pada tabel 5 diketahui sebanyak $26(14,6 \%)$ subyek penelitian berada pada kategori tingkat spiritualitas tinggi. Sedangkan sebanyak 126 atau sebesar 70,8 persen berada pada kategori sedang, dan $26(14,6 \%)$ subyek penelitian menunjukkan tingkat spiritualitas rendah. Berdasarkan pada uraian di atas dapat disimpulkan bahwa kesehatan mental dan spiritualitas subyek penelitian berada pada kategori sedang.

Pengujian hipotesis penelitian dilakukan dengan analisis regresi. Hasil analisis pengaruh variabel spiritualitas terhadap variabel kesehatan mental menunjukkan bahwa $\mathrm{R}=0,353$ dengan koefisien determinan sebesar 0,125 , berarti spiritualitas mampu menjadi prediktor sebesar $12,5 \%$ bagi tinggi rendahnya kesehatan mental. Dengan demikian, hipotesis yang menyatakan bahwa spiritualitas berpengaruh terhadap kesehatan mental diterima. Semakin tinggi tingkat spiritualitas, maka semakin tinggi pula tingkat kesehatan mentalnya. Sebaliknya semakin rendah tingkat spiritualitas, maka akan semakin rendah pula tingkat kesehatan mentalnya.

Hasil analisis pengaruh antara spiritualitas dengan kesehatan mental menunjukkan korelasi sebesar $\mathrm{r}=$ 0,353 dan $P=0,000$. Hasil ini menunjukkan bahwa variabel spiritual berpengaruh secara signifikan terhadap kesehatan mental.

Kesehatan mental merupakan kondisi sejahtera pada individu dimana dia dapat mengembangkan potensipotensinya, mampu mengatasi stress secara normal, dan dapat melakukan fungsi sosial dengan baik, serta dapat melaksanakan pekerjaan secara produktif. Sehingga kesehatan mental tidak hanya dipahami sebagai ketidakadaan atau absennya penyakit fisik saja.

Ada banyak faktor yang mempengaruhi tinggi rendahnya kesehatan mental seseorang, salah satunya adalah spiritualitas. Berkaitan dengan hipotesa tersebut, penelitian ini bertujuan untuk menguji pengaruh atau hubungan antara spiritualitas dengan kesehatan mental. Hasil analisis penelitian ini menunjukkan bahwa spiritualitas mampu menjadi prediktor bagi tinggi rendahnya kesehatan mental pada mahasiswa baru fakultas Ilmu Tarbiyah dan Kependidikan (FITK) UIN Maliki Malang. Sehingga hipotesis penelitian yang menyatakan spiritualitas berpengaruh terhadap kesehatan mental diterima.

Hasil penelitian ini menguatkan hasil penelitian yang telah dilakukan sebelumnya, diantaranya penelitian yang dilakukan oleh Fehring, Brennan, \& Keller, (1987) yang menunjukkan bahwa spiritualitas mahasiswa berkorelasi positif dengan kesejahteraan mahasiswa dan secara negatif berkorelasi dengan depresi. Kontribusi spiritualitas terhadap kesehatan mental juga didukung oleh penelitian yang dilakukan oleh Nelms, Hutchins, Hutchins, \& Pursley, (2007) yang menyatakan spiritualitas memiliki hubungan dengan kesehatan fisik dan kesehatan emosi pada mahasiswa. Demikian juga dengan penelitian yang dilakukan oleh Compton, (2001) menunjukkan bahwa tingkat spiritualitas dan religiusitas mempengaruhi tingkat kesejahteraan subyektif dan perkembangan kepribadian pada mahasiswa di perguruan tinggi.

Hasil penelitian ini sejalan juga dengan pendapat Weber \& Pargament, (2014) yang menyatakan bahwa spiritualitas dapat mempengaruhi tinggi rendahnya kesehatan mental. Menurut Weber dan Pargamet, jika sebelumnya dalam lapangan psikologis klinis spiritualitas dan agama memberi kontribusi terhadap sakit mental, namun pada perkembangan berikutnya justruh spiritualitas memberi kontribusi yang menguntungkan bagi meningkatnya kesehatan mental masyarakat, kesejahteran sosial, emosional, dan kualitas hidup yang bahagia. Pendapat weber dan Pargement tersebut berdasarkan pada beberapa penelitian yang telah ada sebelumnya, diantaranya penelitian yang dilakukan oleh Koenig dalam lapangan psikologi klinis. Hasil penelitian Koenig menunjukkan bahwa spiritualitas dan keyakinan agama memiliki pengaruh bagi kesehatan mental pada para penderita depresi, stress, dan mampu mengurangi dorongan untuk melakukan tindakan bunuh diri (Koenig, Al Zaben, \& Khalifa, 2012). Begitu juga penelitian yang dilakukan oleh Mohr et al., (2011) menunjukkan bahwa spiritualitas efektif untuk penyembuhan penderita schizophrenia yang merupakan salah satu gangguan kesehatan mental.

Selain dalam area psikologi klinis, hasil penelitian ini juga menguatkan penelitian pengaruh spiritual terhadap kesehatan mental pada area pendidikan khususnya perguruan tinggi. Seperti penelitian yang dilakukan 
oleh Fehring, Brennan, \& Keller (1987) yang menyatakan bahwa ada pengaruh spiritualitas terhadap kesejahteraan psikologi mahasiswa yang tengah menghadapi perubahan-perubahan hidup spiritualitas mahasiswa mampu mengurangi stress dan depresi. Menurut penelitian tersebut spiritualitas yang dimiliki oleh mahasiswa mampu menghindarkan mahasiswa dari kondisi-kondisi stres atau depresi akibat dari penyesuaian diri terhadap lingkungan dan sistem pembelajaran yang baru.

Ditinjau dari usia, subyek penelitian berada pada tahap remaja akhir atau kaum muda yang sebagian besar berusia antara 18 dan 19 tahun. Pada masa remaja akhir, salah satu karakteristik subyek berada masa akhir pencarian identitas diri, di mana mereka sering mengalami kondisi psikologis yang kurang sejahterah (sering mengalami kondisi emosi tidak stabil, depresi, dan kebimbangan, serta rendahnya). Remaja akhir juga sering mengalami problema dengan lingkungan sosial akibat dari perbedaan cara pandang atau persepsi terhadap norma-norma serta aturan-aturan yang berlaku dilingkungan sosial. Sejalan dengan review yang dikemukakan oleh Wong, Rew, \& Slaikeu (2006) terhadap penelitian-penelitian sejenis sebelumnya. Mereka menyimpulkan bahwa pada remaja dan kaum muda yang memiliki spiritualitas lebih baik dan keyakinan terhadap agama cenderung memiliki self esteem yang tinggi serta tingkat kebahagian yang lebih baik. Mereka juga terhindar dari ketergantungan pada alkohol dan obat-obat terlarang.

Rentannya mahasiswa sebagai kaum muda mengalami masalah mental saat ini tengah mendapatkan perhatian dari berbagai pihak, masyarakat, pemerintah, maupun para praktisi dari berbagai latar belakang. Terwujudnya kesehatan mental (mental health) kaum muda merupakan salah satu tujuan dari pembangunan manusia secara utuh yang merupakan komponen penting bagi kekuatan masyarakat, produktivitas, perdamaian dan stabilitas lingkungan hidup serta memberi kontribusi terhadap modal sosial dan pembangunan ekonomi (Auerbach et al., 2018). Kaum muda yang sehat secara mental adalah individu yang merasa sejahtera, menyadari kemampuannya, serta dapat mengatasi tekanan-tekanan dalam kehidupannya, dapat bekerja secara baik dan produktif, serta mampu memberi kontribusi kepada masyarakatnya. Dalam lapangan pendidikan khususnya pada jenjang pendidikan perguruan tinggi, hasil penelitian ini menguatkan pula penelitian-penelitian sebelumnya, di antaranya penelitian yang dilakukan oleh Fehring yang menyatakan bahwa ada pengaruh spiritualitas terhadap kesejahteraan psikologi mahasiswa yang tengah menghadapi perubahan-perubahan hidup, spiritualitas mahasiswa mampu mengurangi stress dan depresi.

Spiritualitas salah satu faktor yang mempengaruhi tingkat kesehatan mental pada kaum muda. Beberapa penelitian menunjukkan bahwa remaja yang kuat secara spiritual atau agama memiliki kesehatan mental yang lebih baik (Bhui et al., 2005). Lebih tahan terhadap tekanan-tekanan hidup yang dihadapi dan relatif lebih bahagia (Abdel-Khalek, 2015). Dari hasil temua-temuan dalam penelitian terdahulu dan penelitian ini dapat dijelaskan bahwa ada pengaruh spiritualitas dengan kesehatan mental. Di mana pada lapangan pendidikan, tingkat spiritualitas yang mempengaruhi tingkat kesehatan mental bukan hanya secara individual saja tetapi juga lembaga. Secara individual, spiritualitas yang baik akan berpengaruh terhadap kesehatan mental peserta didik. Peseta didik yang memiliki kesehatan mental akan menunjukkan beberapa kondisi positif pada aspek kognitif, emosi, dan perilaku. Peningkatan perhatian kesehatan mental dalam dunia pendidikan didasarkan pada buktibukti yang menyatakan bahwa kesehatan mental memiliki kontribusi terhadap perkembangan dan kesuksesan akademik mahasiswa. Menurut Kitzrow, kesehatan mental memiliki dampak yang cukup kuat terhadap kehidupan lingkungan kampus. Baik pada level individual, interpersonal, maupun level institusional(Alzaeem et al., 2010).

Pada level individual, problema kesehatan mental akan berpengaruh terhadap semua aspek yang ada pada diri mahasiswa, baik aspek emosional, kognitif, fisik, dan sosial atau terganggunya hubungan antar individu. Pengaruh tersebut dapat dilihat dalam bentuk munculnya gejala-gejala umum depresi seperti terganggunya suasana hati, keletihan, lemahnya energi, problema dengan pola makan dan tidur, konsentrasi yang buruk, rendahnya motivasi dan self esteem, lemahnya kemampuan mengingat dan pengambilan keputusan, hilangnya semangat untuk menjalani aktivitas secara normal dan menarik diri dari lingkungan sosial, serta kondisi yang lebih esktrim melarikan diri dari rumah dan bahkan bunuh diri.

Problema kesehatan mental juga dapat berpengaruh negatif terhadap performansi akademik, perhatian, dan tingkat kelulusan mahasiswa. Penelitian yang dilakukan oleh Alzaeem et al., (2010) dan Carter (2016) menunjukkan bahwa pada mahasiswa yang memiliki gangguan kesehatan mental dalam bentuk stres memperlihatkan adanya penurunan produktifitas, sulit berkonsentrasi, kemampuan mengingat informasi sangat terbatas, mempengaruhi pengambilan keputusan, dan terganggunya kesehatan. Demikian juga penelitian yang dilakukan oleh Brackney \& Karabenick (1995) telah menguatkan bukti bahwa problema kesehatan mental berpengaruh terhadap performan akademik mahasiswa. Penelitian keduanya menemukan bahwa tingkat distress psikologis yang tinggi diantara para mahasiswa secara signifikan dikaitkan dengan performan akademik. 
Karakteristik mahasiswa dengan tingkat distress psikologi yang tinggi ditunjukkan dengan skor tes kecemasan yang tinggi, rendahnya self efficacy pada bidang akademik, kemampuan mengelola waktu dan penggunaan sumber-sumber belajar yang kurang efektif, kurang mampu menghadapi kondisi sulit, rendahnya kemampuan menggunakan strategi-strategi belajar.

Secara interpersonal, mahasiswa dengan kondisi kesehatan mental yang bermasalah cenderung memiliki masalah secara emosional maupun perilaku dalam bentuk perilaku-perilaku distruptif, mengganggu, dan perilaku-perilaku berbahaya lainnya, bahkan yang lebih ekstrim adalah perilaku menyakiti diri sendiri maupun orang lain. Kondisi demikian dapat mengganggu hubungan mereka dengan orang lain, baik dengan teman sekelas, para staff, ataupun pengajar menjadi kurang harmonis (Alzaeem et al., 2010).

Secara institusional, setiap perguruan tinggi memiliki visi dan misi yang dicapai. Pencapaian visi dan misi tersebut perlu didukung oleh seluruh sivitas akademik yang salah satu diantaranya adalah mahasiswa. Dalam konteks ini, kesehatan mental mahasiswa baik secara langsung maupun tidak dapat memberi dampak terhadap keberhasilan pencapaian visi dan misi perguruan tinggi.

\section{KESIMPULAN}

Hasil penelitian ini menunjukkan bahwa spiritualitas memiliki pengaruh terhadap kesehatan mental pada mahasiswa. Dengan demikian dapat dikatakan bahwa hasil penelitian ini menguatkan hasil penelitian sebelumnya yang menyatakan bahwa spiritualitas memiliki kontribusi bagi kesehatan mental mahasiswa. Hasil penelitian ini juga menunjukkan bahwa jenis kelamin tidak berpengaruh signifikan terhadap tingkat spiritualitas dan kesehatan mental pada mahasiswa.

\section{REFERENSI}

Abdel-Khalek, A. M. (2015). Happiness, health, and religiosity among Lebanese young adults. Cogent Psychology, 2(1), 1035927.

Alzaeem, A. Y., Sulaiman, S. A. S., \& Gillani, S. W. (2010). Assessment of the validity and reliability for a newly developed Stress in Academic Life Scale (SALS) for pharmacy undergraduates. International Journal of Collaborative Research on Internal Medicine \& Public Health, 2(7), 239.

Auerbach, R. P., Mortier, P., Bruffaerts, R., Alonso, J., Benjet, C., Cuijpers, P., ... WHO WMH-ICS Collaborators. (2018). WHO World Mental Health Surveys International College Student Project: Prevalence and distribution of mental disorders. Journal of Abnormal Psychology, 127(7), 623-638. https://doi.org/10.1037/abn0000362

Bhugra, D., Till, A., \& Sartorius, N. (2013). What is mental health? International Journal of Social Psychiatry, 59(1), 3-4. https://doi.org/10.1177/0020764012463315

Bhui, K., Stansfeld, S., Head, J., Haines, M., Hillier, S., Taylor, S., ... Booy, R. (2005). Cultural identity, acculturation, and mental health among adolescents in east London's multiethnic community. Journal of Epidemiology \& Community Health, 59(4), 296-302.

Blanco, C., Okuda, M., Wright, C., Hasin, D. S., Grant, B. F., Liu, S.-M., \& Olfson, M. (2008). Mental Health of College Students and Their Non-College-Attending Peers: Results From the National Epidemiologic Study on Alcohol and Related Conditions. Archives of General Psychiatry, 65(12), 1429-1437. https://doi.org/10.1001/archpsyc.65.12.1429

Brackney, B. E., \& Karabenick, S. A. (1995a). Psychopathology and academic performance: The role of motivation and learning strategies. Journal of Counseling Psychology, 42(4), 456.

Brackney, B. E., \& Karabenick, S. A. (1995b). Psychopathology and academic performance: The role of motivation and learning strategies. Journal of Counseling Psychology, 42(4), 456.

Carter, B. N. (2016). Association of Religious Commitment and Perceived Stress Levels in College Students.

Compton, W. C. (2001). Toward a tripartite factor structure of mental health: Subjective well-being, personal growth, and religiosity. The Journal of Psychology, 135(5), 486-500.

Dangel, T. (2019). Associations between Multidimensional Spirituality and Mental Health: Positive Psychological Traits as Mediators. Disertassion, (12), 111.

Etopio, A. L., Devereux, P., \& Crowder, M. (2018). Perceived campus safety as a mediator of the link between gender and mental health in a national U.S. college sample. Women \& Health, 1-15. https://doi.org/10.1080/03630242.2018.1549646

Fehring, R. J., Brennan, P. F., \& Keller, M. L. (1987a). Psychological and spiritual well-being in college students. Research in Nursing \& Health, 10(6), 391-398. 
Fehring, R. J., Brennan, P. F., \& Keller, M. L. (1987b). Psychological and spiritual well-being in college students. Research in Nursing \& Health, 10(6), 391-398.

Hasson-Ohayon, I., Mashiach-Eizenberg, M., Lavi-Rotenberg, A., Brüne, M., \& Roe, D. (2019). Emotion identification among people with serious mental illnesses: The role of specific emotions and sex. Psychiatry Research. https://doi.org/10.1016/j.psychres.2019.01.082

Hernandez, B. C. (2011). The religiosity and spirituality scale for youth: development and initial validation. Dissertation, 42.

Hodapp, B., \& Zwingmann, C. (2019). Religiosity/Spirituality and Mental Health: A Meta-analysis of Studies from the German-Speaking Area. Journal of Religion and Health. https://doi.org/10.1007/s10943-01900759-0

Jafari, E., Dehshiri, G. R., Eskandari, H., Najafi, M., Heshmati, R., \& Hoseinifar, J. (2010). Spiritual well-being and mental health in university students. Procedia-Social and Behavioral Sciences, 5, 1477-1481.

Keyes, C. L., \& Lopez, S. J. (2002). Toward a science of mental health. Handbook of Positive Psychology, 4559.

Kitzrow, M. A. (2009). The mental health needs of today's college students: Challenges and recommendations. NASPA Journal, 46(4), 646-660.

Koenig, H. G., \& Al Shohaib, S. S. (2019). Religiosity and Mental Health in Islam. In H. S. Moffic, J. Peteet, A. Z. Hankir, \& R. Awaad (Eds.), Islamophobia and Psychiatry (pp. 55-65). https://doi.org/10.1007/978-3030-00512-2_5

Koenig, H. G., Al Zaben, F., \& Khalifa, D. A. (2012). Religion, spirituality and mental health in the West and the Middle East. Asian Journal of Psychiatry, 5(2), 180-182.

Manwell, L. A., Barbic, S. P., Roberts, K., Durisko, Z., Lee, C., Ware, E., \& McKenzie, K. (2015). What is mental health? Evidence towards a new definition from a mixed methods multidisciplinary international survey. BMJ Open, 5(6), e007079-e007079. https://doi.org/10.1136/bmjopen-2014-007079

Mohr, S., Perroud, N., Gillieron, C., Brandt, P.-Y., Rieben, I., Borras, L., \& Huguelet, P. (2011). Spirituality and religiousness as predictive factors of outcome in schizophrenia and schizo-affective disorders. Psychiatry Research, 186(2-3), 177-182.

Nelms, L. W., Hutchins, E., Hutchins, D., \& Pursley, R. J. (2007). Spirituality and the Health of College Students. Journal of Religion and Health, 46(2), 249-265. https://doi.org/10.1007/s10943-006-9075-0

Pant, N., \& Srivastava, S. K. (2019). The Impact of Spiritual Intelligence, Gender and Educational Background on Mental Health Among College Students. Journal of Religion and Health, 58(1), 87-108. https://doi.org/10.1007/s10943-017-0529-3

Park, N. S., Lee, B. S., Sun, F., Klemmack, D. L., Roff, L. L., \& Koenig, H. G. (2013). Typologies of religiousness/spirituality: Implications for health and well-being. Journal of Religion and Health, 52(3), $828-839$.

Sartorius, N. (2002). Fighting for Mental Health: A Personal View. Cambridge University Press.

Weber, S. R., \& Pargament, K. I. (2014). The role of religion and spirituality in mental health. Current Opinion in Psychiatry, 27(5), 358-363.

Wong, Y. J., Rew, L., \& Slaikeu, K. D. (2006). A systematic review of recent research on adolescent religiosity/spirituality and mental health. Issues in Mental Health Nursing, 27(2), 161-183. 